\title{
ASSESSMENT OF PRODUCTION EQUIPMENT OF CHOSEN ROLLING MILL IN POLAND
}

\author{
${ }^{1}$ Manuela INGALDI, ${ }^{2}$ Magdalena MAZUR \\ ${ }^{1}$ Czestochowa University of Technology, Faculty of Management, Czestochowa, Poland, EU, \\ manuela.ingaldi@wz.pcz.pl; manuela@gazeta.pl \\ ${ }^{1}$ Czestochowa University of Technology, Faculty of Management, Czestochowa, Poland, EU, \\ magdalena.mazur@wz.pcz.pl
}

https://doi.org/10.37904/metal.2020.3647

\begin{abstract}
Appropriate maintenance of machinery and production equipment allows for smooth production, eliminates downtime related to failures, improves work safety and improves the productivity of an enterprise. Wellfunctioning machines allow for production of high-quality products. This is an important topic especially in enterprises of the metallurgical industry due to the specificity. They usually work in system 24/7, what is more, machines and devices are used in the most effective way possible. In addition, an important factor is the ability to produce products with appropriate quality parameters, because many of these products are used, e.g. in various machines, vehicles, constructions or buildings. The purpose of the paper was to assess the production devices of one of the rolling mills in Poland in terms of its condition and use. Chosen technical and technological indicators typical of metallurgical enterprises were used for this assessment. This research covered 5 consecutive years. Slight fluctuations in the values of the research indicators were noted, which is why the machine breaks were additionally examined.
\end{abstract}

Keywords: Rolling mill, production equipment, modernity, productivity

\section{INTRODUCTION}

The maintenance department, which is responsible for maintaining the suitability of equipment for carrying out production processes, is part of every production system. Currently, this department is also part of the analysis of the effectiveness of processes that are part of the overall efficiency of implemented manufacturing processes [1]. The basic issue in this respect is the TPM concept, which includes the tasks of maintaining equipment for operation in processes, supervising the efficiency indicators of these machines, and the direct impact on the production capacity and productivity of manufacturing processes $[2,3]$. The TPM system is one of the foundations of the Lean Management concept, which is based on the elimination of basic types of waste, also those related to the operation of machinery and production equipment [4].

The technical condition and quality of used machines and devices directly affect the downtime in the implementation of the production schedule. This element of waste in the production system has a significant impact on the implementation of the assumed production plan and on the flexibility function of organized production process. Therefore, properly prepared strategies for the maintenance of machines is the basis for maintaining the production capacity of the system for the production and realizations of orders in the planned time periods [5]. The importance of machine maintenance strategies is enhanced by the high level of highscale production automation and mechanization as well as the long service life of the used equipment $[6,7]$. Taking into account these elements and their importance, maintenance is the basis deciding about manufacturing capabilities, but in accordance with the principles of Lean Management, they are also subject to the principles of optimization and adequate efficiency of operations that apply to all corporate resources, 
without exception. The main idea related to maintenance is to prepare parts and machines to do what is required in the allocated time and sizes, and to do it with less resources $[8,9]$.

The TPM concept uses two basic indicators. Firstly, it is focused on minimizing waste in the production and operation of equipment from the point of view of the use of production capacities that have been planned. Secondly, it focuses on the quality of created products, where the main goal is to achieve a zero level of product defects [10]. These two elements still allow reducing the amount of production scrap or reducing the defect rate, no breakdown, no accidents, no waste during the process or replacement [11]. Numerous publications based on the implementation and use of the TPM concept show the benefits for the production system in terms of eliminating waste of time (according to the number of breakdowns as well as the number of production defects and the resulting corrective actions). Monitoring and calculating the main indicator of the efficiency and productivity of the use of the machine park also gives the company information at what stage of the strategy implementation is, where weak points in the organization of production are, and as a consequence of further analysis also about way of possible improvement $[12,13]$.

Metallurgical enterprises belong to those enterprises that work in a continuous system, which means that production devices are used 24/7. Maintenance and repairs of machines must be properly planned so as not to cause too long stoppages in production and reduction of the company's productivity and efficiency.

The purpose of the paper was to assess the production devices of one of the rolling mills in Poland in terms of its condition and use. Chosen technical and technological indicators typical of metallurgical enterprises were used for this assessment. This research covered 5 consecutive years.

\section{METHODOLOGY}

An assessment of the rolling mill production equipment in one of the steelwork in Poland was conducted. The indicators for the research were chosen from the point of view of the specificity of the operation in the research enterprise and collected data. The estimation of the technical work equipment, which is used in the structures of the enterprise, illustrates the dependence of the replacement value of the machine park and labor inputs as well as the work efficiency achieved with the use of these resources. This indicator is the result element of the implemented TPM strategy and the principles of maintaining machinery and equipment in the technological line. The technical work equipment is the most general and most common indicator showing the technical level of an enterprise. This indicator is the ratio of value of fixed production assets to the number of employees [14]:

Technical work equipment $=\frac{\text { value of fixed production assets }}{\text { employment }}$

The numerator "may include all fixed assets or only the so-called active part of fixed assets (machinery and technical equipment without buildings)" [15]. This part of the analysis of production resources is related to technical progress that may occur in the enterprise. The increase in value of equipment enhances the production force and in some way facilitates human work, which is expressed in higher productivity.

When assessing the productivity of fixed assets or production assets, the research focuses primarily on assessing the relationship between fixed assets and the volume of production. Therefore, an important indicator that presents the efficiency relationship is the indicator showing the ratio of achieved production effects per $1 \mathrm{PLN}$ of fixed assets involved in the production process [14]:

Productivity of fixed production assets $=\frac{\text { production }}{\text { average value of fixed production assets }}$

Fixed production assets involvement indicator have an absorbent nature. It presents the opposite attitude to the productivity of fixed production assets. It represents the amount of fixed assets involved per unit of production volume. In the literature it is often called the indicator of capital intensity or material intensity [16]. This indicator is calculated according to the following formula [17]: 
Fixed production assets involvement indicator $=\frac{\text { average value of fixed production assets }}{\text { production }}$

Efficiency of use of production equipment is measured by the time of their work in the course of production. The most frequently calculated indicator is work time indicator for production equipment, presenting the ratio of the effective working time to the maximum possible to use working time [15]:

Working time indicator for production equipment $=\frac{\text { sum of the effective working time }}{\text { sum of the maximum possible to use working time }}$

To illustrate the extent to which production machines and equipment were not used, the breaks time indicator can be used. It can be calculated as follows [15]:

Breaks time indicator for production equipment $=\frac{\text { number of breaks hours }}{\text { sum of the maximum possible to use working time }}$

There are no specific values for individual indicators in the literature, because their level depends on many factors. However, it is worth calculating them at regular intervals and comparing them to assess the overall situation of the company.

In addition, an analysis of the causes of breaks in the rolling mill was carried out. The percentage shares of individual causes of breaks were calculated for each year in the analyzed period.

\section{RESULTS}

Table 1 presents summary of calculated indicators in the research period. To calculate these indicators, the value of production machinery and equipment of the chosen rolling mill was taken into account.

Table 1 Summary of indicators in the research period [own study]

\begin{tabular}{|c|c|c|c|c|c|}
\hline Indicator & Year 1 & Year 2 & Year 3 & Year 4 & Year 5 \\
\hline Technical work equipment [PLN/person] & 509453.42 & 469646.47 & 398311.98 & 339327.97 & 299302.57 \\
\hline Productivity of fixed production assets [kg/PLN] & 2.49 & 2.62 & 3.66 & 4.82 & 4.25 \\
\hline Fixed production assets involvement indicator [PLN/Mg] & 400.90 & 381.10 & 273.47 & 207.36 & 235.17 \\
\hline Working time indicator for production equipment & 0.787 & 0.787 & 0.813 & 0.762 & 0.687 \\
\hline Breaks time indicator for production equipment & 0.213 & 0.213 & 0.187 & 0.238 & 0.313 \\
\hline
\end{tabular}

In the case of the research rolling mill, the technical work equipment was systematically decreasing. This was related to changes in the means of production, as there were no major changes in the volume of employment. That is why this situation was related only to the general aging of the machine park and the lack of new investments in recent years.

Productivity of fixed production assets and fixed production assets involvement indicator deserve a lot of attention. Despite a clear decrease in the value of production assets, these changes do not coincide with changes in the production volume. What's more, it is possible to notice a continuous increase in productivity, except for last year of research period, when small decrease of the indicator was observed. This means that despite the decrease in the value of production means and the lack of investment, the rolling mill is able to produce the high amount of products. The decrease of the indicator in year 5 was caused by a decrease in orders for products, and thus a decrease in general production. The opposite situation was illustrated by fixed production assets involvement indicator. There was less and less fixed production assets for the production of $1 \mathrm{Mg}$ of products. With the exception of year 5 , when production volume dropped dramatically, and thus a slight increase in the indicator was noted, which was caused by a decrease in demand.

Working time indicator for production equipment informs about the rational use of production means. The higher the value of the indicator is, the better the use of working time is. It can be seen that in year 1 and year 
2 working time indicators were at the same level. In the following year, the rolling mill utilized the working time of the production means in over $0.813 \%$, unfortunately in the last year only in almost $0.687 \%$. Breaks time indicator for production equipment informs about level of breaks in working time. The high value of this indicator means low rationality of using the means of production. High value of this indicator was noted in year 5 . This means that over 0.313 of the maximum possible to use time consists of different types of breaks in work of the rolling mean.

However, one important thing should be emphasized that will be seen later in the further analysis. Research rolling mill produces different types of products, different dimensions of these products, which is associated with the need for frequent changeover of the rolling mill. Additionally, the production plan includes periodic inspections and planned renovations of the rolling mill resulting from maintenance. Therefore, maximum possible to use time cannot be fully used.

Fluctuations in the value of breaks time indicator for production equipment in individual years of the research period caused the need for additional research. The causes of breaks in work of the research rolling mill were analyzed. Table 2 presents the causes and percentage shares of individual causes of breaks in the research period.

Table 1 Summary of breaks in work of rolling mill in the research period, [\%] [own study]

\begin{tabular}{|c|c|c|c|c|c|}
\hline Causes of breaks & Year 1 & Year 2 & Year 3 & Year 4 & Year 5 \\
\hline technological & 73.08 & 84.21 & 87.71 & 76.46 & 75.05 \\
\hline defects & 0.00 & 0.12 & 0.36 & 11.71 & 10.58 \\
\hline mechanical & 2.74 & 3.34 & 3.42 & 3.80 & 4.94 \\
\hline electric & 4.67 & 3.64 & 3.20 & 3.26 & 4.09 \\
\hline energetic & 1.83 & 1.15 & 0.95 & 1.51 & 1.40 \\
\hline external & 0.00 & 0.49 & 0.73 & 0.48 & 0.55 \\
\hline organizational, including: & 8.84 & 7.04 & 3.64 & 1.39 & 3.39 \\
\hline - lack of material & 0.00 & 3.28 & 2.40 & 0.00 & 0.00 \\
\hline - re-heating of material & 0.00 & 0.36 & 0.00 & 0.00 & 0.00 \\
\hline - other organizational reasons & 8.84 & 3.40 & 1.24 & 1.39 & 3.39 \\
\hline
\end{tabular}

Throughout the entire research period, technological breaks had the largest share in all breaks. As mentioned earlier, they are associated with all kinds of technological changes, primarily with machine as equipment changeover but also inspections and repairs. However, some differences in the proportion of these breaks can be seen. In year 2 and 3 the share of such breaks was around $85 \%$, in the remaining years around $75 \%$. This means that in the remaining years, the share of other, less desirable breaks increased.

In year 4 and 5 a large share of breaks due to different production defects can be seen. This was related to the increase in the number of defects during this period. They were caused by many factors: material defects (poor material composition) and technical factors resulting from the general condition of the equipment [13]. Mechanical breaks are associated with rolling mill breakdowns. However, there were no large differences in share of this type of breaks. In the whole research period, this share did not exceed $5 \%$ of the total break time. This level of breaks was caused by the implementation of TPM principles and inspections and repairs at the rolling mill operation resulting from maintenance. A similar situation was noted in the case of electrical breaks, i.e. all the downtime associated with the lack of electricity or failures related to electricity. In the whole research period, this share was below $5 \%$. Organizational breaks are noteworthy. Their large share was recorded in year 1 and 2. In the case of year 1, these were primarily other organizational breaks (breaks related to additional days or free hours not previously planned). In case of year 2, apart from this reason, the lack of 
material also dominated, i.e. the lack of billets for production. In the same year there were breaks related to the need to re-heat material before rolling. To avoid production defect and to modernize production, rolling mill management should start investing more in production resources. Along with a decrease in the value of production means, their aging occurs, which results in greater system failure rate and more frequent defects.

\section{CONCLUSION}

The condition of production machines and devices influences not only the course of the production process, but above all the quality of manufactured products. That is why proper management of machine exploitation is so important. Among the methods that are helpful in this case, it is necessary to highlight the TPM system functioning, among others, under the concept of Lean Management. TPM includes planned inspections and periodic repairs to avoid waste related to e.g. breakdowns or defects of products $[18,19]$. The products from the research rolling mill are used in many industries, e.g. in various types of constructions, machines, cars or buildings. The proper quality of materials used in such constructions affects not only their quality but also the user's safety. In the paper the use of rolling mill production machinery and equipment in one of Polish steelworks was presented. Technical and technical indicators were used. The analysis showed that the production equipment was aging due to a lack of investment, but its overall condition should be considered good. Despite the decrease in the value of fixed assets, it is possible to produce the right amount of products in accordance with orders. The working time of the machines was approx. $80 \%$, except for the last research year, when this level was below $70 \%$. Nevertheless, it should be remembered that the breaks time should also include the time spent on the changeover of the rolling mill, so that a wide range of products can be produced. However, some investments in modernization of the machine park is needed because there has been an increase in the number of defect. Such a careful approach to maintaining the machine park and thus ensuring the safety of employees can also be useful in other industries, e.g. industrial soldering [20], biotechnology $[21,22]$ or laser machining $[23,24]$. It may be also used in similar approaches to decision support [25] and evaluation methodology $[26,27]$.

\section{ACKNOWLEDGEMENTS}

\section{Research and publication financed from statutory research of the Czestochowa University of Technology BS/PB-6000/3010/2020.}

\section{REFERENCES}

[1] NOWICKA-SKOWRON, M., ULEWICZ, R. Quality management in logistics processes in metal branch. In 24th International conference on metallurgy and materials, In METAL 2015: 24th Int. Conf. on Metallurgy and Materials. Ostrava: TANGER, 2015, pp. 1707-1712.

[2] MAZUR, M., MOMENI, H. Lean Production issues in the organization of the company - results. Production Engineering Archives. 2019, vol. 22, pp. 50-53, doi: 10.30657/pea.2019.22.10.

[3] MASZKE, A., DWORNICKA, R., ULEWICZ, R. Problems in the Implementation of the Lean Concept at a Steel Works - Case Study. MATEC Web of Conferences. 2018, vol. 183, doi: 10.1051/matecconf/201818301014.

[4] MASZKE, A. The analysis of machine operation and equipment loss in ironworks and steelworks, Production Engineering Archives. 2017, vol. 17, pp. 45-48. doi: 10.30657/pea.2017.17.10.

[5] ULEWICZ, R., SELEJDAK, J., BORKOWSKI, S., JAGUSIAK-KOCIK, M., Process management in the cast iron foundry. In METAL 2013: 22 ${ }^{\text {nd }}$ Int. Conf. on Metallurgy and Materials. Ostrava: TANGER, 2013, pp. 1926-1931.

[6] SÖDERHOLM, P., NILSEN, T. Systematic risk-analysis to support a living maintenance programme for railway infrastructure. Journal of Quality in Maintenance Engineering. 2017, vol. 23, no. 3, pp. 326-340, doi: 10.1108/JQME-09-2016-0042. 
[7] GÁLOVÁ, K., RAJNOHA, R., ONDRA, P. The use of industrial lean management methods in the economics practice: An empirical study of the production companies in the Czech Republic. Polish Journal of Management Studies. 2018, vol. 17, iss. 1, pp. 93-104, DOI: 10.17512/pjms.2018.17.1.08.

[8] ALMEANAZEL, O.T.R. Total Productive Maintenance Review and Overall Equipment Effectiveness Measurement. Jordan Journal of Mechanical and Industrial Engineering. 2010, vol. 4, no. 4, pp. 517-522.

[9] WUDHIKARN, R. Implementation of overall equipment effectiveness in wire mesh manufacturing. In 2011 IEEE International Conference on Industrial Engineering and Engineering Management, IEEE, 2011, pp. 819-823.

[10] LYSANOV, D.M., KARAMYSHEV, A.N., EREMINA, I.II. Comparative Evaluation Of Quality Characteristics Of Process Equipment. Astra Salvensis. 2017, year V, no. 10, pp. 217-223.

[11] SHARMA, R.K., DINESH, K., PRADEEP, K. Manufacturing excellence through TPM implementation: a practical analysis. Industrial Management \& Data System. 2006, vol.106, pp. 256-280.

[12] KNOP, K., MIKULOVÁ, P. Evaluation of the Level of Work Safety, Advancement and Efficiency of the Use of Machines and Devices on Labelling and Packaging Line and an Attempt to Compare the Results Using the Modified McKinsey Matrix. System Safety: Human-Technical Facility-Environment. 2019, vol.1, iss. 1, pp. 189196.

[13] KLIMECKA-TATAR, D., DWORNICKA, R. The Assembly Process Stability Assessment Based on the Strength Parameters Statistical Control of Complex Metal Products. In METAL 2019: 28 ${ }^{\text {th }}$ Int. Conf. on Metallurgy and Materials. Ostrava: TANGER, 2019, pp. 709-714.

[14] JANASZ, W., URBAŃCZYK, E., WAŚNIEWSKI, T. Gospodarka środkami trwałymi w przedsiębiorstwie. Warszawa: Państwowe Wydawnictwo Ekonomiczna, 1988.

[15] SOBCZYK, G. (ed.) Ekonomika przedsiębiorstwa. Zbiór przykładów i zadań. Lublin: Wyd. UMCS, 1995.

[16] GRABARA, A.S. Ekonomika i organizacja pracy w przedsiębiorstwie. Częstochowa: Skrypt uczelniany PCz, 1986.

[17] INGALDI, M., DZIUBA, S.T. The Use of the FMEA Method for Qualitative Analysis of Steel Bars. In METAL 2018: $27^{\text {th }}$ Int. Conf. on Metallurgy and Materials. Ostrava: TANGER, 2018, pp. 1996-2001.

[18] TABOR, J. Maintenance management and occupational safety in manufacturing organizations. Polish Journal of Management Studies. 2014, vol. 10, iss. 2, pp. 225-235.

[19] KRYNKE, M., MIELCZAREK, K., VAŠKO, A. Analysis of the Problem of Staff Allocation to Work Stations. Conf. Quality Production Improvement - CQPI. 2019, vol. 1, iss. 1, pp. 545-550, doi: 10.2478/cqpi-2019-0073.

[20] PIETRASZEK, J., GADEK-MOSZCZAK, A., TORUNSKI, T. Modeling of Errors Counting System for PCB Soldered in the Wave Soldering Technology. Advanced Materials Research. 2014, vol.874, pp. 139-143.

[21] SKRZYPCZAK-PIETRASZEK, E., PISKA, K., PIETRASZEK, J. Enhanced production of the pharmaceutically important polyphenolic compounds in Vitex agnus castus L. shoot cultures by precursor feeding strategy. Engineering in Life Sciences. 2018, vol. 18, pp. 287-297.

[22] SKRZYPCZAK-PIETRASZEK, E., KWIECIEN, I., GOLDYN, A., PIETRASZEK, J. HPLC-DAD analysis of arbutin produced from hydroquinone in a biotransformation process in Origanum majorana L. shoot culture. Phytochemistry Letters. 2017, vol. 20, pp. 443-448.

[23] GADEK-MOSZCZAK, A., RADEK, N., WRONSKI, S., TARASIUK, J. Application the 3D Image Analysis Techniques for Assessment the Quality of Material Surface Layer Before and After Laser Treatment. Advanced Materials Research-Switz. 2014, vol.874, pp.133-138.

[24] RADEK, N., BARTKOWIAK, K. Laser treatment of electro-spark coatings deposited in the carbon steel substrate with using nanostructured WC-Cu electrodes. Physics Procedia. 2012, vol. 39, pp. 295-301.

[25] PACANA, A., PASTERNAK-MALICKA, M., ZAWADA. M., RADON-CHOLEWA, A. Decision support in the production of packaging films by cost-quality analysis. Przemysl Chemiczny. 2016, vol. 95, pp. 1042-1044.

[26] BORKOWSKI, S., ULEWICZ, R., SELEJDAK, J., KONSTANCIAK, M., KLIMECKA-TATAR, D. The use of 3x3 matrix to evaluation of ribbed wire manufacturing technology. In METAL 2012: $21^{\text {st }}$ Int. Conf. on Metallurgy and Materials. Ostrava: TANGER, 2012, pp. 1722-1728.

[27] SYGUT, P., KLIMECKA-TATAR, D., BORKOWSKI, S. Theoretical Analysis of the Influence of Longitudinal Stress Changes on Band Dimensions During Continuous Rolling Process. Archives of Metallurgy and Materials. 2016, vol. 16, iss. 1, pp. 183-188, doi: 10.1515/amm-2016-0032. 